
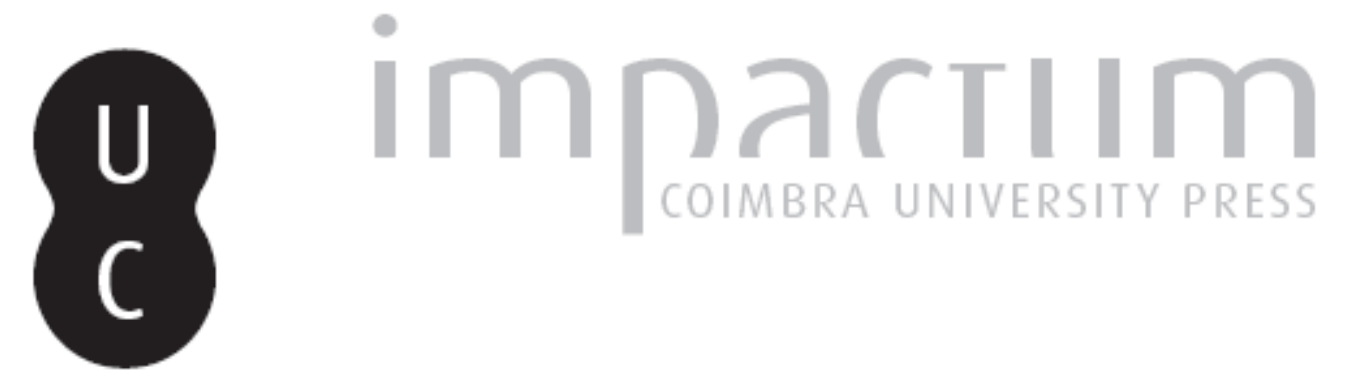

\title{
Do pão de Deus ao pão que o Diabo amassou
}

\section{Autor(es): $\quad$ Fonseca, Carlos da}

Publicado por: Imprensa da Universidade de Coimbra

URL persistente:

URI:http://hdl.handle.net/10316.2/45270

DOI:

DOI:https://doi.org/10.14195/2183-8925_8-1_10

Accessed : $\quad$ 26-Apr-2023 12:40:24

A navegação consulta e descarregamento dos títulos inseridos nas Bibliotecas Digitais UC Digitalis, UC Pombalina e UC Impactum, pressupõem a aceitação plena e sem reservas dos Termos e Condições de Uso destas Bibliotecas Digitais, disponíveis em https://digitalis.uc.pt/pt-pt/termos.

Conforme exposto nos referidos Termos e Condições de Uso, o descarregamento de títulos de acesso restrito requer uma licença válida de autorização devendo o utilizador aceder ao(s) documento(s) a partir de um endereço de IP da instituição detentora da supramencionada licença.

Ao utilizador é apenas permitido o descarregamento para uso pessoal, pelo que o emprego do(s) título(s) descarregado(s) para outro fim, designadamente comercial, carece de autorização do respetivo autor ou editor da obra.

Na medida em que todas as obras da UC Digitalis se encontram protegidas pelo Código do Direito de Autor e Direitos Conexos e demais legislação aplicável, toda a cópia, parcial ou total, deste documento, nos casos em que é legalmente admitida, deverá conter ou fazer-se acompanhar por este aviso.

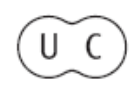


REVISTA DE HISTÓRIA DAS IDEIAS $\mathbf{8}$

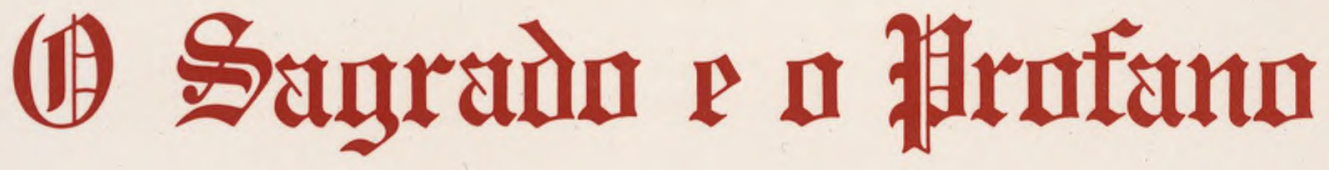 s.1. \\ HOMENAGEM A J. S. DA SILVA DIAS}

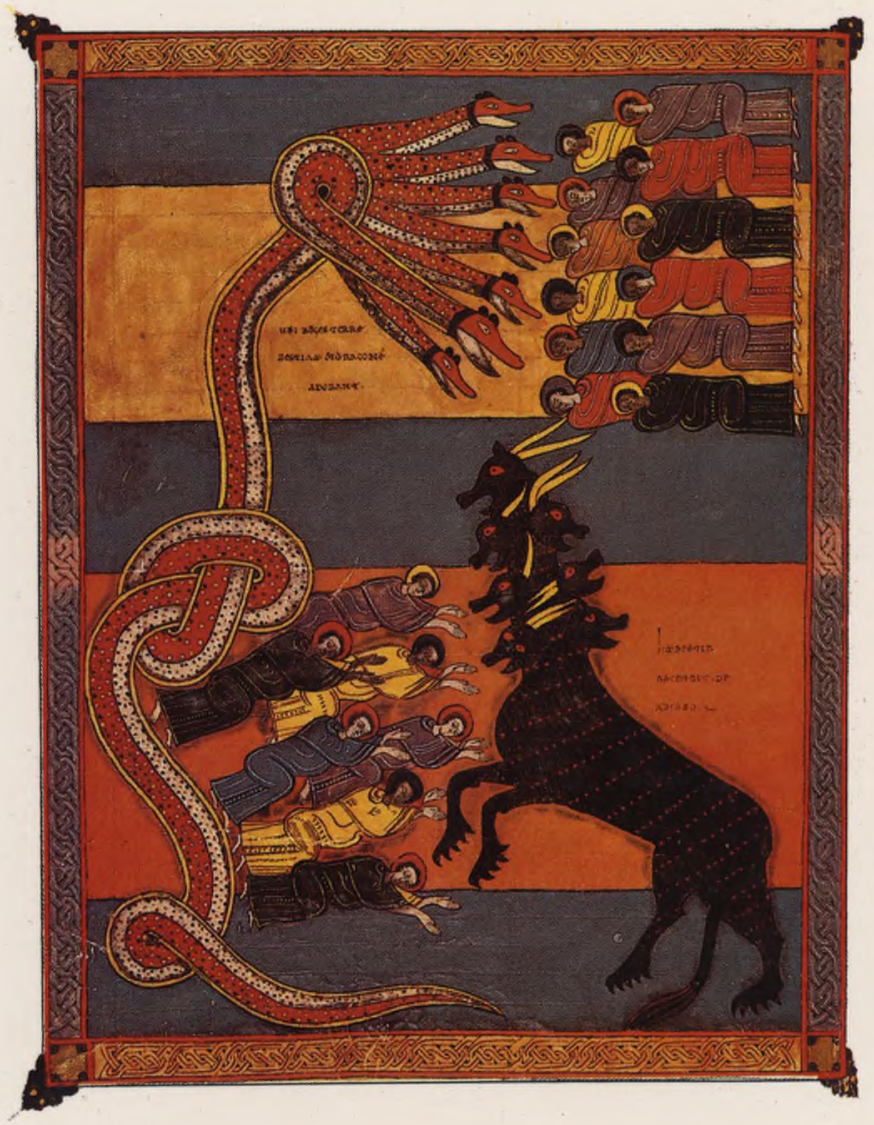

INSTITUTO DE HISTORIA E TEORIA DAS IDEIAS FACULDADE DE LETRAS 


\section{DO PÃO DE DEUS AO PÃO QUE O DIABO AMASSOU}

Ninguém contesta o lugar privilegiado que o pão ocupa há vários séculos nas práticas alimentares portuguesas. Muito antes da generalização do trigo, já os nossos longínquos antepassados o confeccionavam à base de bolota. Graças aos contactos das tribos ibéricas com os povos comerciantes do Mediterrâneo, a cultura de cereais precede a conquista peninsular pelas legiões romanas. A acção renovadora da romanização foi, em primeiro lugar, de ter dilatado consideravelmente a superfície dedicada ao grão, depois, de ter introduzido novas técnicas de panificação e moagem, como o atestam os frequentes achados de mós, do tipo descrito há já muito tempo por Rocha Peixoto 0). A conversão dos povos peninsulares ao cristianismo consagrou definitivamente o pão, colocando-o no centro da constelação alimentar de todas as classes.

Infelizmente não são só às qualidades nutritivas, nem ao seu valor de uso, que este produto essencial deve tão longo e retumbante sucesso. Durante séculos o grão constituiu o verdadeiro valor monetário nas operações económicas. Tributos, rendas, foros, etc., exprimiam-se quase sempre em alqueires, moios, carros de pão ou pães cozidos e só muito raramente em dinheiro. Nenhum outro género alimentar custou às classes pobres tantas expoliações e vexames cometidos por nobres, clérigos e burgueses. Sobre o pão recaiam também os impostos mais significativos, quer locais (portagens), quer alfandegários, quer sobre o consumo. *

* Universidade de Paris VIII.

O) Portugália, t. 1 , fase. 1 a 4 . 


\section{O Sagrado e o Profano}

Chamar «pão político» a certas atitudes governamentais perante tão grave problema, parece-nos no caso português, enunciar uma tautologia. A política do pão levou as naus portuguesas à aventura norte africana no século $\mathrm{XV}$, forçou D. Fernando a decretar a Lei das Sesmarias, impeliu Pombal ao arranque violento das vinhas, gerou o aberrante proteccionismo de 1893, provocou as revoltas da fome de 1915-1919 e as agitações contra o pão hierarquizado dos anos vinte, fez surgir a tão discutida Campanha do Trigo salazarista. Que não há pão sem política, é pois uma verdade elementar!

Raramente o trigo nacional satisfez as necessidades internas do consumo. Indolência, rotina, indiferença, falta de capitais...., tudo impedia a emancipação cerealífera. E, como diz o ditado: «casa onde não há pão, todos ralham e ninguém tem razão»!

Doutra natureza era o obstáculo de um solo pobre, dificilmente transformável em celeiro. Houve mesmo quem, atendendo às circunstâncias, sugerisse soluções radicais:

«Aparece ainda a razão de que se o pão estrangeiro entrasse livremente, a terra portuguesa ficaria impossibilitada de o produzir.... Para cinco milhões de portugueses poderem comer pão barato é preciso que o país desista da cultura do trigo. Aceitemos a tese como verdadeira.

Se o fosse morreríamos todos, haveria algum cataclismo, acabar-se-ia o mundo?

De duas uma: ou a terra portuguesa tem as qualidades precisas para produzir pão e nesse caso trata de produzir em condições que possam lutar com a concorrência, ou não tem, e nesse caso parece mais prático ver bem qual seja o seu destino. E sempre um erro contrariar a natureza.

Se ela não manda produzir pão, produza-se uvas, batatas, cebolas, flores, ou o que ela indicar e se porventura demonstrar que nada disso pode produzir e apenas tem força para dar pinheiros, faça-se a sementeira dum grande pinhal de Faro até Bragança» $\left({ }^{2}\right)$.

Entre 1865 e 1888 o trigo exótico representava $29,7 \%$ do consumo nacional, $44,3 \%$ entre 1889 e $1898,33,1 \%$ de 1899 a 1914 , $35,6 \%$ em $1915-1920,41,4 \%$ de 1921 a 1929 e $11,2 \%$ no período de 1930-1939.

Durante o livre-cambismo, até 1890 aproximadamente, o déficit nacional era compensado por importações da Rússia e dos Estados Unidos. Nos anos de fraca produção mundial a

(2) João Baptista de Barros, Causas da Carestia do Pão em Portugal, Lisboa, Casa dos Tipógrafos, 1913, p. 7. 
fome assolava as cidades portuguesas mas o preço do pão mantinha-se dentro de limites razoáveis, mercê do sacrifício do ágio de ouro. Desde 1889 recorreu-se às medidas proteccionistas, tímidas ao princípio, depois reforçadas por novos diplomas em 1893, 1899, 1905, 1911, etc.

Estabeleciam as leis protectoras que nenhum trigo fosse adquirido no mercado internacional antes da produção portuguesa ter sido completamente absorvida pela indústria moageira, na esperança legítima de incentivarem o aproveitamento dos terrenos incultos, de popularizarem a utilização de fertilizantes e de modernizarem as técnicas agrícolas. Nos cálculos do seu inspirador, Elvino de Brito, os sacrifícios consentidos em benefício da lavoura conduziriam a um aumento da superfície cultivada, com consequências positivas tanto na produção como na produtividade. Atingidos esses objectivos, o pão nacional alinhar-se-ia automaticamente pelos preços mundiais e $\mathrm{o}$ Estado desembaraçava-se da hemorragia financeira.

Mas o tempo passava e cada ano agrícola era um desmentido categórico das teses oficiais. Não só continuávamos a ocupar a cauda da Europa em rendimento por hectare, mas a própria produção per capita baixava nos primeiros anos de proteccionismo, como o demonstrou um especialista da questão:

Produção de trigo expresso em kg por habitante $\left(^{3}\right)$

$\begin{array}{ll}1865-1888 & 37 \mathrm{~kg} \\ 1889-1898 & 32,5 \mathrm{~kg} \\ 1899-1914 & 38,7 \mathrm{~kg} \\ 1915-1920 & 37.4 \mathrm{~kg} \\ 1921-1929 & 44,2 \mathrm{~kg} \\ 1930-1939 & 68.4 \mathrm{~kg}\end{array}$

Em nome dum aleatório «progresso da lavoura», o governo forçava os moageiros a desembolsarem 68 réis por $\mathrm{kg}$ de trigo duro, quando o mole, de superior qualidade, cotava apenas 43 réis no mercado mundial. De 1900 a 1908 a protecção aos seareiros custou ao consumidor a bagatela de 40000 contos de réis sem a compensação de um resultado mesmo parcial: «Não pode - protestavam os numerosos adversários de semelhante legislação - vigorar por mais tempo o vigente regime cerealífero que obriga as classes pobres a pagarem com o preço

(3) Henrique de Barros, O Problema do Trigo, 3. a ed., Lisboa, Biblioteca Cosmos, 1944, p. 128. 
elevadíssimo do pão - alimento de primeira necessidade - às custas da protecção dispensada à agricultura» $\left({ }^{4}\right)$.

A fachada desenvolvimentista escondia a realidade dum chorudo negócio para três beneficiários. Aos lavradores assegurava-se a compra dos stocks a 68 réis o quilograma. A moagem combateu a imposição por algum tempo, fingindo aliar-se ao expoliado consumidor. Se comíamos o pão mais caro da Europa, dizia, era por vontade do Estado que «impingia» à força o trigo nacional e adicionava um imposto de 17 réis por $\mathrm{kg}$ ao trigo importado por 43 réis. De facto a operação rendia anualmente uma média de 679 contos de réis de que os esfomeados cofres públicos eram os beneficiários.

As críticas da moagem, interesseiras como eram, tinham o mérito de denunciar um absurdo económico. O trigo nacional, obrigatório, dava aos industriais «apenas» 23,44 réis de lucro por kg de farinha, quando o exótico lhes dava 31,5 réis.

Viu-se portanto, o governo, na imperiosa necessidade de calar a boca à moagem, associando-a à negociata com a compensação de algumas regalias. Surgiu assim o famoso decreto de 26 de Setembro de 1893, assinado pelo republicano Bernardino Machado. Doravante ficava estabelecido em 250 o limite máximo de padarias em Lisboa e recusavam-se novas licenças. Estava banida a livre concorrência no interior do mercado lisbonense, servido em argêntea bandeja aos panificadores-moageiros. Como se isso não chegasse, o decreto de 17 de Maio de 1906 proibiu a venda em Lisboa de pão cozido fora da área, isto é, deu à moagem um verdadeiro monopólio territorial.

Defendida pelo republicano Século, protegida pela igualmente republicana vereação camarária, constituiu-se em 1902 a Companhia de Panificação Lisbonense. Na direcção pontificava António Castanheira de Moura, protagonista instigador do sombrio «drama dos Olivais», de que resultou o fuzilamento à queima roupa de três sindicalistas, em 28 de Maio de 1924.

Tal um polvo insaciável, o novo organismo não tarda a apoderar-se das licenças das padarias independentes. Nesta tarefa a cumplicidade dos poderes instituídos foi mais do que evidente. A pretexto de condições higiénicas impostas pelo decreto de 26 de Julho de 1899, a Câmara aterrorizava os pobres padeiros com repetidas vistorias e sanções. Aos que, apesar das perseguições recusavam desfazer-se do seu «ganha pão», a Companhia Lisbonense reservava a asfixia pela recusa das farinhas.

(4) Ao Povo Português - Pão Barato - O Problema Cerealifero em Portugal, Lisboa, Tip. Calçada de Sant'Ana, s. d. [1913], p. 3. 
Em 1911 a limitação das padarias na capital concentrara nos «tentáculos do monstro» 241 licenças $\left(^{5}\right)$. Se não fossem as 14 padarias independentes e algumas cooperativas de panificação ainda activas, todo o lisboeta se via obrigado a ingerir o pão amassado pelo diabo.

«Se tu queres que t'eu diga

Quem são os quatro ladrões

São vendeiros e moleiros

E letrados e escrivães» $\left(^{6}\right)$.

Prova cabal da importância do pão na economia doméstica, é a forma expeditiva e unânime como o povo amarra atafoneiros ou moleiros ao pelourinho da infầmia.

A péssima reputação do moleiro não se limita ao facto de maquiar abusivamente os clientes. Há entre ele e o maligno qualquer coisa de comum, um pacto de união que lhe confere poderes de curandeiro e de bruxo. A crença de que o moinho é uma invenção infernal, um lugar habitado pelo diabo, é comum a todos os povos europeus $\left({ }^{7}\right)$. O isolamento do moleiro em relação à comunidade aldeã, acentua-lhe a misantropia, transforma-o em sátiro regional aos olhos das populações. Por vezes o estigma da velhacaria precede o exercício da profissão, como se, para ser moleiro, houvesse uma espécie de predestinação: «Diabo perdido meteu-se em moleiro», diz-se na Beira Alta. Porém, a faceta mais hedionda do seu comportamento, a mais umversalmente detestada, é a maneira desonesta como manipula uma matéria que, depois de amassada e cozida, incarna simbolicamente o corpo de Cristo. Dar joio por trigo, cal por farinha ou roubar nas medidas, merece punição exemplar: «O moleiro por ser ladrão - justicia o povo - vai para o inferno com a maquia na mão».

Por se tratar de um produto de características sagradas e profanas, a repressão das fraudes assumia logicamente o duplo aspecto religioso e civil. Em Idanha-a-Nova judeus e moleiros

(5) Limite de Padarias na Cidade de Lisboa - Representação Dirigida ao Ex.mo Sr. Ministro do Fomento pela Assembleia de Accionistas e Obrigacionistas da Companhia de Panificação Lisbonense, Lisboa, Typ. Ed. José Bastos, 1911.

(6) A. C. Pires de Lima, «Tradições Populares de Santo Tirso», Lisboa, Revista Lusitana XVII, 1914, XVIII, 1915 e XIX, 1916.

$\left.{ }^{7}\right)$ V. Armando de Lucena, Arte Popular, Usos \& Costumes Portugueses, vol. I, 2. ${ }^{\text {a }}$ ed., Lisboa, Empresa Nacional de Publicidade, 1944, p. 161. 
eram excluidos das confrarias $\left.{ }^{8}\right)$. Noutras terras do país as casas dos moleiros não eram sequer visitadas na Páscoa.

Nos grandes centros, as autoridades eclesiásticas eram menos severas. Aí, os moleiros viviam sob a protecção de Santo Antão, incorporando-se como as demais profissões na procissão do Corpus Christi. Vigiar comportamentos e punir abusos, eram atribuições exclusivas do Senado da Câmara. Ora, roubar no peso das farinhas, constituía um crime profissional severamente punido nos regimentos corporativos: «pela primeira vez q. for comprehendido em dar menos farinha seraa posto na picota a vergonha onde estaraa duas horas, e pela segunda vez haveraa vinte açoutes ao pee do pilourinho, e nao seraa mais atafaneiro» $\left({ }^{9}\right)$.

Mais do que os moleiros, quase sempre estabelecidos extra-muros, eram os fabricantes de pão objecto de cerrada vigilância. As posturas do Senado obrigando ao respeito da qualidade, do peso legal, do preço estabelecido, etc., provam a vontade da Câmara em respeitar as reivindicações populares. $\mathrm{O}$ que mais contrariava a eficácia dos inspectores camarários eram as condições particulares do fabrico do pão. Até ao século XIX a profissão de padeiro foi exercida quase em exclusividade pelo elemento feminino. Para escapar aos fiscais e aos impostos, grande parte das padeiras trabalhavam clandestinamente. Depois de feitas às escondidas, as fornadas desse pão incontrolável eram encaminhadas em segredo para as tendas e tabernas. De tal forma se desenvolveu a «economia subterrânea» que a Câmara de Lisboa impôs, em princípios do século XVIII, o uso de tabuletas anunciando a venda.

Nem as tabuletas, nem as sanções pecuniárias, nem os açoites públicos, nem inclusive, a perda da profissão, conseguiram proteger o pobre consumidor dos astuciosos moleiros e padeiros. A guerra do pão continuou, agravando-se mesmo no século XIX, com o advento do manipulador profissional e da moagem industrial, como adiante veremos.

Se o pão mereceu tantas atenções, foi por ser a componente mais importante da alimentação do povo português em geral, e das classes modestas, em particular. Por ordem decrescente de consumo temos, em primeiro lugar, indivíduos de profissões não sedentárias ou pesadas, como os rurais, corti-

$\left.{ }^{8}\right)$ Jaime Lopes Dias, Etnografia da Beira, vol. V, Lisboa, Livraria Ferin, 1939, p. 73.

$\left.{ }^{9}\right)$ Virgilio Correia, Livro dos Regimentos dos Officiaes mecânicos da mui nobre e sempre leal cidade de Lisboa (1572), Coimbra, Imprensa da Universidade, 1926, p. 180. 
ceiros, pescadores, carregadores, etc. Logo a seguir vêm os operários fabris, seguidos a boa distância dos empregados. Os menos «panívoros» são os burocratas e os intelectuais citadinos $\left({ }^{10}\right)$. Em 1873 o pão ocupava o primeiro lugar dos géneros diariamente ingeridos pelo jornaleiro do Alentejo e do Ribatejo:

$\begin{array}{lc}\text { Pão (com 40\% de água) } & 1000 \mathrm{~g} \\ \text { Azeite } & \mathbf{2 0} \\ \text { Bacalhau ou sardinha } & \mathbf{1 0 0} \\ \text { Vinho } & \mathbf{2 0 0} \\ \text { Legumes } & 250 \\ \text { Batatas } & 600(11)\end{array}$

Antes da invenção dos transportes modernos e da submissão do campo à cidade, a panificação era tributária da distribuição geográfica dos cereais. Segundo o economista Anselmo de Andrade, em 1900 o trigo constituía 95\% do pão comido em Lisboa, Portalegre, Évora e Beja. Em Faro a percentagem atingia ainda 85\%. A média era de 36\% em Santarém, Leiria e Porto. Em Aveiro, Braga, Bragança, Vila Real, Coimbra e Castelo Branco, 18\%. A Guarda, Viana do Castelo e Viseu eram os distritos menos permeáveis à espiga dourada, com $12 \%\left({ }^{12}\right)$.

Enquanto o sul desprezava o pincadilho, comedor de broa, nas próprias zonas de milheiro a evolução das sensibilidades alimentares opera-se favorável ao trigo. Uma quadra nortenha diz sugestivamente:

$$
\begin{aligned}
& \text { «Não há pão como o pão alvo, } \\
& \text { nem carne como o carneiro } \\
& \text { nem peixe como a pescada, } \\
& \text { nem amor como o primeiro». }
\end{aligned}
$$

Se o trigo era considerado um regalo, muitas vezes reservado para dias de festa, não era apenas por arremedo dos hábitos citadinos. Só a pureza, tantas vezes confundida com a alvura, era digna de representar o Corpo de Cristo em dias de festividade religiosa ou familiar. À brancura do trigo aliavate a sensação de um pão menos indigesto pela sua leveza.

(10) V. por ex.: I Colóquio sobre Cereais Farinhas Pão II, Lisboa, Grémio dos Industriais de Panificação de Lisboa, 1964, p. 73.

$\mathrm{C}^{11}$ ) António Augusto Mendes Correia, A Alimentaçăo do Povo Português, Lisboa, Centro de Estudos Demográficos, MCMLI, p. 32. p. 41.

(i2) Portugal Económico, Lisboa, Manuel Gomes, MDĊCCCII, 
«Pão tremez, nem o comas nem o dês», aconselha o adágio. Não quer isto dizer que os preconceitos não tivessem contribuído para a derrota do milho e do centeio. Júlio de Melo e Matos sustenta-o diante da Liga Agrária do Norte: $" O$ trigo é considerado o pão dos ricos, o pão das cidades, um pão melhor, mais apetecido pela tendência inata do português às pompas vãs do luxo» $\left({ }^{13}\right)$.

Sem discordarmos do argumento psicológico, parece-nos, no entanto, mais correcto atribuir a mudança à dissolução das autarcias técnico-económicas, ao desaparecimento de sistemas primitivos de moagem, de fornos, do combustível espontâneo (lenha), etc., incapazes de competir com a indústria citadina. Isto em primeiro lugar. Depois, a própria evolução dos hábitos alimentares, cujo exame mostra uma constante diminuição no consumo de pão. Entre 1927 e 1936, a média diária era de 428 gramas por habitante. De 1937 a 1946, 384 g. Estamos portanto muito longe dos 9 quilogramas semanais que entravam no avio do trabalhador rural alentejano à volta de 1900 , ou das 483 g quotidianas do lisboeta em $1910\left({ }^{14}\right)$. Ora são precisamente o milho e o centeio, tão ligados às economias regionais e caseiras, quem maior recuo acusou.

Concluir sobre um eventual eclipse do pão nas nossas mesas, seria um grave erro de apreciação. As classes pobres continuam e continuarão a apreciar-lhe a modicidade e as qualidades nutritivas. Mesmo endurecido, o pão é demasiado precioso para se deitar fora. Nos lares modestos transforma-se em migas, ensopado, açorda, capacho, cachola e outras delícias concebidas pelo economia doméstica.

Amassada a farinha e traçada a cruz na pasta, as mulheres do concelho de Gondomar, diziam antes de fechar a masseira:

«São Vicente te acrescente

São Silvestre te levede,

São João te faça pão

E Nosso Senhor te ponha a sua virtude» $\left({ }^{15}\right)$.

(13) Os Pães Regionais, Porto, Liga Agrária do Norte, s. d. [1935?], p. 13.

(14) V. respectivamente: Silva Picão, Através dos Campos, Lisboa, Dom Quixote, 1983 e Simão de Martel, A Alimentação das Classes Pobres e as suas Relações com o Trabalho, Lisboa, Imprensa Nacional, 1911.

(15) Camilo de Oliveira, O Concelho de Gondomar (Apontamentos Monográficos), Porto, Empresa Moderna, 1938, vol. IV, p. 390. 
$\mathrm{Na}$ maioria das religiões o grão é apresentado como uma dádiva dos deuses misericordiosos feita ao homem. Se nos nossos dias a relação entre céu e terra se tornou imperceptível mercê da laicização quotidiana, se poucos vêm já no pão a incarnação corpórea ou espiritual de Cristo, subsistem no entanto certas crenças que ultrapassam a simples questão do paladar. Um exemplo excepcional diz respeito ao chamado pão caseiro, símbolo, para muitos citadinos, do suor do pai, da dedicação angélica da mãe e, do reconhecimento dos filhos. Este pão (e o saloio ou provinciano por generalização), incarna as virtudes familiares, atribui-se-lhe qualidades nutritivas superiores graças à pureza do grão, das farinhas, ao esmero da fabricação. Pouco importa se o milho provoca a pelagra ou se do centeio resulta, em certas condições, a gangrena das extremidades. Através do pão o consumidor idealiza a vida «simples», «pura» e «saudável» do campo, em oposição à corrupção citadina, à vida febril, à sede de dinheiro.

Talvez se trate duma ilusão de ruralistas nostálgicos, mas seria difícil atribuir tais virtudes ao pão citadino e anónimo dos moageiros. Os nomes populares dados ao casqueiro lisboeta sugerem quase sempre a má qualidade: papo seco, carcaça, cacete, etc.

Até ao século XVIII apenas as disposições dos regimentos corporativos falam da higiene do pão. Nessa altura nomearam-se Provedores de Saúde cuja missão era detectar quaisquer anomalias apresentadas pelo grão ou pelas farinhas. $O$ chamado «trigo do mar», isto é, o que chegava do estrangeiro a bordo de navios, merecia particular atenção. Quando cheirava a bafio, os padeiros eram obrigados a amassá-lo com água cozida em erva doce. Aos homens e mulheres que o padejavam ou joeiravam nas tercenas, proibia-se de dormirem naqueles locais. Receava-se então, que o trigo infeccionado comunicasse a doença aos humanos. Eram medidas necessárias mas insuficientes, pois deixavam em toda a liberdade as atafonas, moinhos, azenhas e até as padarias.

Com o desenvolvimento da moagem moderna no século XIX não melhoraram as condições de higiene, nem a qualidade do pão. Os jornais denunciavam constantemente os vestígios de sangue, bocados de cordel, excrementos de ratos, baratas e outras impurezas. O paladar era azedo, a cor negra e o aspecto repugnante. Deste pão amassado pelo diabo, ingeria o povo de Lisboa entre 100 e $200 \mathrm{mil} \mathrm{kg} \mathrm{diariamente}$

$\mathrm{O}$ pão anónimo, maculado e amargo é um produto típico dos moageiros. Se aparenta alvura, não é, pela qualidade da farinha, mas pela maquia de cal adicionada. É amassado e cozido por manipuladores mal pagos, em regime de trabalho nocturno, 
portanto sem qualquer carinho. Quase sempre o manipulador pernoita no forno entre a masseira e a farinha, sobre uma enxerga empestada de parasitas. A atmosfera é desidratante, saturada de poeira. As paredes são negras de fumo e o chão asqueroso.

Em vez de equilibrar a nutrição, o pão é muitas vezes o veículo de doenças. Em 1929 os manipuladores denunciavam: «A classe dos Manipuladores de Pão.... não quer ter a mínima responsabilidade na fabricação deste produto que, longe de ser um alimento, é pelo contrário, o causador da maior parte das doenças desconhecidas que na sua tarefa mortífera vão desvastando a população» $\left({ }^{16}\right)$.

Nem todos os consumidores estavam sujeitos a semelhante «argamassa». Havia o pão dos ricos e o dos pobres, separados por uma hierarquia já praticada no antigo regime, embora menos vincada. Até ao aparecimento das ideias socialistas o pão hierarquizado foi aceite pelas classes pobres como uma fatalidade irremediável. Alimentavam-se de pão inferior como resignadamente habitavam os prédios mais modestos ou viajariam mais tarde em carruagens de 2. ${ }^{\mathrm{a}}$ e $3 .^{\mathrm{a}}$ classe. $\mathrm{O}$ mais humilhante era ser obrigado a pagar por preço elevado um produto que muitos animais recusariam:

Preços do pão de trigo em Lisboa e Porto

\begin{tabular}{r|c|l|l|l|l|l|l|l}
\hline & 1912 & $\begin{array}{l}\text { Jul. } \\
1914\end{array}$ & $\begin{array}{r}\text { Maio } \\
1915\end{array}$ & $\begin{array}{c}\text { Set. } \\
1916\end{array}$ & $\begin{array}{l}\text { Jan. } \\
1917\end{array}$ & $\begin{array}{l}\text { Set. } \\
1917\end{array}$ & $\begin{array}{c}\text { Set. } \\
1922\end{array}$ & $\begin{array}{c}\text { Ag. } \\
1923\end{array}$ \\
\cline { 2 - 8 } L. - de 1. & $\$ 10$ & $\$ 09$ & $\$ 09$ & $\$ 17$ & $\$ 30$ & $\$ 47$ & $2 \$ 00$ & $3 \$ 00$ \\
$2 .^{\mathrm{a}}$ & $\$ 09$ & $\$ 08$ & $\$ 08$ & $\$ 10$ & $\$ 12$ & - & $\$ 62$ & $1 \$ 80$ \\
$3 .^{\mathrm{a}}$ & $\$ 08$ & - & - & - & - & - & $\$ 40$ & $1 \$ 00$ \\
P._de 1.a & - & $\$ 10,5$ & $\$ 12$ & $\$ 17$ & $\$ 30$ & $\$ 40$ & - & - \\
$2 .^{\mathrm{a}}$ & - & $\$ 08,5$ & $\$ 10$ & $\$ 15,5$ & - & $\$ 28$ & - & - \\
\hline
\end{tabular}

Enquanto um quilograma custava ao lisboeta 90 réis, entre 1905 e 1912 , o parisiense pagava 72,5 réis por um produto qualitativamente superior.

Para democratizar o pão à sua maneira, a República criou aquela «argamassa» azeda e cinzenta, vulgarmente chamada pão de $3{ }^{\mathrm{a}}$. Era a maior humilhação moral feita às classes tra-

(16) Os Manipuladores de Pão ao Povo de Lisboa - O Pão, Lisboa, Cooperativa Casa dos Gráficos, 1929, p. 2. 
balhadoras por uma burguesia empoleirada no governo à sua custa. De resto a «guerra do pão», acesa em 1911, será uma constante do regime deposto em 1926 pela soldadesca bracarense: 1910-1914, agitação contra o limite das padarias; 1915-1918 , assaltos às padarias, protestos contra a especulação e o mercado negro; greves gerais em Viana do Castelo (15-4-1919), Almada (18-1-1921) e Aljustrel (25-4-1923), contra a falta de pão; greves gerais em Portalegre (7-8-1921), Évora (6 a 9 de Junho de 1922), Santarém (22-8-1923 e 25-2-1924), contra a subida do preço; greves gerais em Lisboa (7-8-1922), país (14-8-1922), e de novo em Lisboa (24 a 29 de Agosto de 1923), contra o pão hierarquizado em três tipos.

Nem sempre a guerra contra a moagem-panificação tomou características tão espectaculares. Quando o regime cerealífero de 1890-1900 instituiu o monopólio, o proletariado tentou combate-lo pacificamente pelo cooperativismo. Para que o pão quotidiano fosse «tragável» surgiram a Alegria, a Liberal, a Libertadora, a dos Manipuladores de Pão, a Padaria do Povo, a Padaria Federal, a Panificadora, a Persistente, a Probidade, todas em Lisboa; a Familiar (Pedrouços), a Social Tomarense, a Conimbricense, a Panificadora Azambrejálense (Loures), Panificadora Económica (Loriga de Cima), a Lacobricense, a Panificia, a de Panificação, Farinhas e Cereais (todas do Porto), etc. $\left({ }^{17}\right)$.

Raras foram as cooperativas que ultrapassaram as modestas dimensões duma pequena loja, mobilada dum balcão e com um forno nas traseiras. Na capital as mais dinâmicas eram a Libertadora e a Panificadora, contando a última 2071 sócios em 1906. No Porto destacou-se a Panificia com 2800 associados em 1925.

Não obstante a pequena envergadura, as cooperativas de panificação tinham nos moageiros e padeiros inimigos jurados. São elas o alvo privilegiado da brochura já citada sobre o limite de padarias: "Apareceu a primeira em 1895. Em 1896 organizam-se duas, e, em 1899, uma.... Em 1902, surgem cooperativas de panificação de todos os lados, em 1904, uma, em 1906, três; em 1907, cinco; em 1908, seis; em 1909, doze, e a febre continua em $1910 \ldots .$. , em 15 anos cerca de 40 cooperativas de panificação» $\left({ }^{18}\right)$. Não dizem os autores do panfleto que muitas delas apenas vendiam pão, não passando outras do projecto, por os moageiros lhes negarem as farinhas.

(17) Carlos da Fonseca, «Role des Coopératives dans l'Economie Libérale Portugaise entre 1871 et 1910» in Le Fait Coopératif et Mutualiste (Actes du Colloque-Limoges, 1981), Limoges, Trames, 1983.

(18) Limite de Padarias...., p. 13. 


\section{O Sagrado e o Profano}

Sem serem subversivos, os cooperativistas quiseram demonstrar a possibilidade de um pão barato e legalmente pesado. Pela prática tentaram destruir as hierarquias, fabricando um tipo único, alvo, saboroso e higiénico. No fundo era o combate do «pão em comum» da solidariedade, com o casqueiro anónimo e corrompido pelo interesse.

Semear, ceifar ou debulhar os cereais, amassar, peneirar a farinha, enfornar ou comer o pão, são gestos banais e quotidianos. Não era assim num passado relativamente próximo, como o indicam as sobrevivências de crenças antigas ou vestígios materiais da actividade humana. $\mathrm{Na}$ província estacam-se ainda as hemorragias nasais com duas palhas cruzadas nas costas do doente, saram-se os tumores com papas de milho preparado em leite de mulher. Cruzes protectoras vigiam as bocas dos fornos, tão eficazes como o «sino-simão» gravado nos espigueiros para afuguentar o mau olhado dos vizinhos invejosos. Com outro instrumento ligado ao pão, a simples peneira, espreita-se o céu, tiram-se sortes, fazem-se revelações. No Alentejo (Beja) faz-se germinar o trigo dentro de água para com ele se decorar o presépio natalício. É a «seara do Menino Jesus». Desde o campo ao celeiro, do moinho à masseira, do forno à mesa, nunca a visão mágico-arcaica do universo deixa de estar presente.

$\mathrm{O}$ acto de comer o pão exige uma série de precalços que só os loucos ou irresponsáveis ignoram. Cortá-lo com faca é sempre de mau agoiro. Só as mãos são dignas de o partir, mas sem o deixar cair no chão. Se tal acontecer, beija-se imediatamente a fim de destruir os malefícios. Cuspir-lhe é pecado grave. Cheirá-lo é expor-se à terrível sentença de a terra não «comer o corpo» depois de morto.

Pão invertido sobre a mesa, traz desgraças para uns, é pecado para outros. Colocá-lo nesta posição, era obrigar Nossa Senhora a permanecer de joelhos, dizem os habitantes de Idanha-a-Nova $\left({ }^{19}\right)$.

Muito mais perigoso era deixar o pão mordido dos dentes. Arriscava o incauto que algum inimigo crivasse o naco com alfinetes e o desse a comer a um sapo. Quantos seres não "definharam a olhos vistos» por um momento de inatenção.... 
Dos alimentos utilizados pelo homem nenhum como o pão concentrou sobre si tanta superstição, foi objecto de tanto culto ou se associou a tantos ritos. Os seus inventores egípcios ofereciam uma medida de trigo à divindade protectora dos cereais ao acabarem as debulhas. Para que os mortos não voltassem com fome, ofereciam-lhes pães, numa cerimónia próxima do nosso «Pão de Deus» do Dia de Todos os Santos. Na Grécia o grão tinha origem sagrada. Era a ressurreição de Persephone (Cora, em dórico), filha de Demeter e de Júpiter, por um processo bastante semelhante à de Jesus Cristo.

Também os romanos, que tanto influenciaram as mentalidades ibéricas, festejavam Ceres protectora dos cereais e Cybele deusa da Agricultura. Teófilo Braga notou certas analogias do culto romano com os ritos e sacrifícios de animais feitos em Nisa pela Eucaristia ${ }^{(20)}$.

As festas da Ascensão, vulgarmente conhecidas pelo «Dia da Espiga», inscrevem-se na mesma tradição. No sul do país a espiga dourada associa-se à oliveira e a flores num ramo protector. Guardado em casa, atrai a fertilidade e afuguenta as trovoadas se se queimarem folhas de oliveira. Em Palmeia o pão cozido entra na composição do talismã. Nele se espeta e se deixa durante todo o ano a espiga dourada. Decorrido esse tempo, cada membro da família come um pequeno pedaço na mira de obter boas colheitas. No Cadaval e Figueira subsistem os mesmos ritos, com uma variante nas margens do Mondego: a espiga deve ser colhida à uma hora da tarde, quando o sol atinge o zénite (21). Também os lisboetas colhiam a espiga pelo arredores da capital na 5. a Feira da Ascensão para que o pão lhes não faltasse durante $o$ ano.

Com a difusão do cristianismo entre as classes populares a devoção dos santos protectores substituiu ou transformou os antigos cultos. Numa oração de Vila Real, Jesus cruza Santa Bárbara e pergunta-lhe onde ia. Atarefada, a santa responde:

«Vou espalhar as trovoadas

Que no céu andam armadas;

Deitá-las para a Serra do Marão

Onde não haja palha, nem grão....» $\left({ }^{22}\right)$.

$\left(^{20}\right)$ o Povo Português nos seus Costumes, Crenças e Tradições,

vol. II, Lisboa, Livraria Ferreira, 1885, p. 291.

${ }^{(21)}$ Ernesto Veiga de Oliveira, «A Quinta Feira da Ascensão em Portugal», Trabalhos de Antropologia e Etnografia, vol. XV, fase. 3-4, Porto, 1955-57, pp. 288-293.

(22) J. Leite de Vasconcelos, «Carmina Mágica do Povo Português»,, A Era Nova, Lisboa, 1881, p. 541. 
A ciência popular, nomeadamente a meteorologia, não hesita, mesmo contradizendo-se, em justificar-se através dos celestes advogados. Se o adágio mais corrente afirma que «Chuva da Ascensão dá pão», na zona de Vinhais desmente-se categoricamente a sentença: «Chuva na Ascensão, fura as nozes e tira o pão».

Com o amassamento entramos nas fases cruciais da grande metamorfose, durante as quais o grão morto pela ceifa e reduzido a pó pela trituração, vai renascer em matéria comestível, em fonte da vida. Depois da acção conjugada da terra com o ar, intervêm agora os outros elementos básicos da vida, a água e o fogo. Amassar o pão é um acto procriador, parte integrante do eterno ciclo vida-morte-vida. O crescimento da pasta na masseira fecundada pelo fermento sugere o desenvolvimento da criança no ventre materno. As amassadeiras protegem-a gravando-lhe uma cruz e, para maior segurança, recitam-lhe:

«S. Vicente/te acrescente

S. Levede/te levede

S. Freigil/te faça vir

S. Abraão/te faça pão....» $\left({ }^{23}\right)$.

É pela vontade de Deus que a massa «levanta»: «Deus aumenta o pão na masseira», afirma o povo e, a intervenção divina reforça a ideia dum Christus Paniformis. Aliás, os interditos relativos ao amassamento, coincidem com o enterro do corpo de Jesus, isto é, com a Semana Santa. Não se amassa Quinta-Feira de Endoenças, nem Sexta-Feira da Paixão porque é amassar com o sangue de Cristo. $\mathrm{O}$ pão feito durante o luto aparece veiado de sangue.

No ventre rubro do forno opera-se a transformação fundamental da cozedura, graças ao fogo sagrado e purificador. Aqui habitam forças misteriosas, geralmente benignas, a quem o homem recorria em caso de doença. Nos fornos introduziam-se os «sarnentos» cobertos de enxofre até «suarem bem». Curava-se também o raquitismo juvenil colocando a criança sobre a pá após a cozedura. Para que o resultado fosse completo a fornada devia ser constituída por nove pães.

Com o cristianismo a cozedura passou a fazer-se sob a protecção de Santa Bárbara, «forneira do Senhor». A cruz destronou por completo os antigos signos gravados na boca do

(23) Exemplo de Vouzela, com variantes noutras terras, in J. Leite de Vasconcelos, Opúsculos, Vol. V. Etnologia, Parte I, Lisboa, Imprensa Nacional, 1938, p. 409. 
forno, embora no Minho e Douro subsistisse o costume de barrar as portas com bosta de boi. A tradição parece derivar do antigo culto solar (o toro é o sol no Rig-Veda), embora o boi tenha merecido a «santificação» por ter bafejado o Menino Jesus.

Quando a última peça da fornada dá entrada no forno, faz-se o sinal da cruz com a pá, acompanhado das seguintes palavras:

«Deus te abençoe/Dentro do forno/e fora do forno, E o meu vizinho/que coma um corno» $\left({ }^{24}\right)$.

Quase sempre o pão tomava uma forma redonda, inspirada talvez no disco solar. Outras havia, no entanto, destinadas a funções nem sempre ligadas à nutrição. No concelho de Eivas o bolo chamado folar dado pela Páscoa aos rapazes e raparigas solteiras, tinha a configuração de um lagarto, um pinto, um borrego ou um pombo. No Norte fabricavam-se os açucarados testículos de S. Gonçalo de Amarante, abundantemente consumidos no primeiro sábado de Junho. Também os padeiros de Lisboa fabricavam com a massa estranhas criaturas e animais que talvez encerassem virtudes especiais. Algumas destas formas, as fálicas em especial, parecem derivar do «bolo de trigo alqueivado», utilizado pelas bruxas a fim de provocarem a fecundidade ou o casamento dos clientes.

De resto as virtudes não eram apanágio exclusivo do pão zoomórfico, nem de tipos especiais como o integral ou de sêmola. «Carne, pão e vinho, fazem o velho menino» diz o popular ditado. Aos convalescentes dava-se uma mistura explosiva de pão com vinho, adoçada com mel ou açúcar. Eram as popularíssimas e milagrosas sopas de cavalo cansado. Para as crianças frágeis ou ougadas, fazia-se um pequeno pão com a massa do meio da masseira (por ficar por baixo da cruz?) onde se introduzia uma gota de azeite por um buraco feito com o dedo. $\mathrm{O}$ doente devia comê-lo atrás da porta e dar-se o resto a um cão preto, se sobejasse.

Talvez por estar em contacto directo com o fogo, a côdea é a parte que maiores poderes encerra. Em três pedaços é um amuleto poderosíssimo contra o bruxedo. No Minho quando a criança saía de noite ao colo da mãe, esta precavia-se da infalível defesa. Quando não tinha pão, substituía-o por um punhado de sal.

(24) J. Leite de Vasconcelos, «Carmina Mágica....», p. 513. 
Comer a parte exterior do pão faz os olhos bonitos, diz-se às crianças em Benquerença. No Porto faz casar cedo, se for a côdea dos cantos. A côdea de pão quente cura a fungagem devida à passagem de sapo ou aranha sobre a epiderme dos adormecidos $\left({ }^{25}\right)$. Enfim, a benéfica crosta, restabelece também os animais vitimados pela inveja. Num só caso, e se for de centeio, o seu efeito é suposto negativo: quando dada aos menores de seis meses pode contagiá-los de «maus ares».

Tratando-se do corpo de Cristo a Igreja não podia tolerar semelhantes manifestações de paganismo. Promoveu o pão benzido chamado a dissolver as antigas crenças, ou quando essas não repugnavam, a sobrepor-se-lhes. $O$ pão gigante fabricado em Pombal em fins de Julho testemunha essa sobreposição. Um homem entrava no forno quente, circulava em redor da massa que de vez em quando tocava nas mãos. É provável que tão desmesurado pão de 8 a 10 alqueires de trigo, seja uma remeniscência do primitivo ciclopismo tão ligado ao fogo e às cavernas $\left({ }^{26}\right)$. As exigências de comungar antes de entrar no forno e de levar na boca uma flor tirada das mãos da Virgem, foram posteriormente adicionadas pelo cristianismo popular.

Com mais energia se combateu o pão mágico da farmacopeia primitiva. Assim o pão benzido da Festa dos Tabuleiros de Tomar constitui um verdadeiro antídoto dos pães fálicos. Só as raparigas vestidas de branco imaculado, isto é, simbolicamente virgens e puras são admitidas no transporte dos tabuleiros.

Noutras regiões a bênção do pão teve origens bastante diferentes. Em Vinhais, por exemplo, a cerimónia era feita pelo Santo Estêvão junto à igreja. Depois da bênção distribuía-se pelos populares que guardavam preciosamente alguns pedaços para curarem os animais doentes. Neste caso o «pão bento» parece destinado a evitar o velho costume do roubo das hóstias, tantas vezes atribuído aos judeus, mas cometido pelos camponeses para darem aos animais doentes.

A cerimónia da bênção suscita o problema de saber se o pão é por si mesmo um alimento divino ou, se para isso, necessita da intervenção sacerdotal. A frase de Cristo «tomai isto é o meu corpo» dirigida aos apóstolos durante a última ceia,

\footnotetext{
(25) Jorge Dias, Rio de Onor. Comunitarismo Agro-Pastoril, Lisboa, Presença, 1981.

(26) Parece-nos fantasiosa a afirmação não documentada do P. e Carvalho da Costa de que a festividade surgiu na sequência duma praga de gafanhotos e lagartos (Corografia Portuguesa). A tradição do «bolo borralho», comum aos povos latinos, era já praticada pelos romanos.
} 


\section{Do Pão de Deus}

cauciona a ideia de transubstanciação, isto é, de que o seu corpo está ali de facto presente.

Tendo em conta a importância do pão na passagem de Jesus pela terra, torna-se difícil dissociá-los. O facto de ter nascido em Belém, cujo nome significa «Casa do Pão», soa como uma predestinação. Mais tarde concede o milagre da multiplicação para saciar os famintos. Por último a mensagem «Eu sou o pão da vida» interpretada naturalísticamente pelo senso popular, completa a ideia dum Christus Paniformis.

Esquecido muito tempo, o pão divino conhecerá uma verdadeira devoção entre o operariado da primeira metade do século XIX, graças ao cristianismo social da época romântica. A partir daí o pão incarna simultaneamente o trabalho, preço a que a humanidade decaída é obrigada para obter a reabilitação, e a nobreza de ser útil. Um poeta popular escreve:

«O trabalho dá o pão

Ao mísero proletário,

O trabalho é o sacrário

Da Santa Religião» ( $\left.{ }^{27}\right)$.

Ter direito ao fruto pressupõe um dispêndio constante da própria vida, um sacrifício corporal, de acordo com o preceito: «Ganharás o teu pão com suor do teu rosto».

ternacional, 1917, p. 6.

Manuel Alves, Versos d'um Cavador, Lisboa, Livraria In- 